Historic, archived document

Do not assume content reflects current scientific knowledge, policies, or practices. 



\section{THE EGYPTIAN VEGETABLE PEACH}

\section{OR MLANGO MELON}

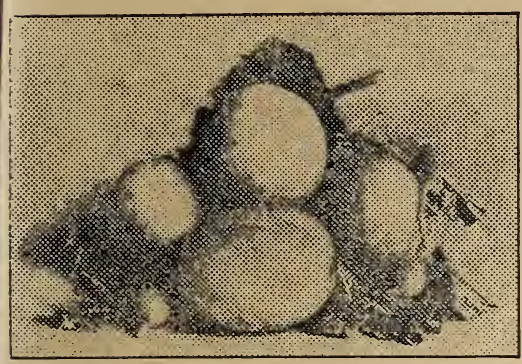

This new and distinct form of Vegetable Marrow is of a running or trailing habit, very short-jointed and extraordinarily prolific. The fruits are globe shaped, are the size of an orange, and when ripe take a deep canary color. In appearance it is more like a Melon than a Marrow; when it is cut open it resembles a Cantaloupe. Instead of the rather insipid watery flesh of the ordinary varieties it is firmer in texture, and possesses a delicate flavor that pleases all who have tried it. The late fruit make an excellent pickle. Use green ginger in flavoring the preserves. It makes a white, transparent jam that is absolutely unequalled.

Full directions for planting, cooking and jam making mailed with every package. We think that we can claim that we have introduced a vegetable that will be welcome in every garden.

Price, 25c per package.

\section{AUSTRALIAN GIANT CABBAGE}

This new and marvelous production has created a tremendous sensation among the gardeners in Australia, New Zealand and Cape Colony (which have climates similar to that of California). It is known as the 100-pound Cabbage and is a most rapid grower and a great blight and drouth resister. Grows enormous heads, very solid and compact, and as hard as a cannon ball, frequently measuring two feet across, with an outer circumference of ten feet.

The quality is unsurpassed for delicacy of flavor and the leaves are fine grained and crisp. It is the most handsome and uniform cabbage grown and Australians highly praise its edible qualities.

Seeds 25c per Package

\section{THE BEAUTIFUL DESERT PEA The Finest Native Flower of Australia}

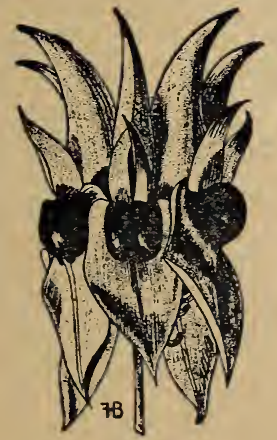

This beautiful plant is a biennial trailer. It is comparatively easy of cultivation, requiring a light sandy soil, well drained, and plenty of heat to bring out its flowers to their highest beauty. They are a brilliant scarlet with intense black spots in the center.

Seeds should be planted where they are to remain, as it will not easily transplant. Tire seeds require to be soaked in hot water before sowing. No new manure must be allowed to come in contact with the plants, but any old lime or building refuse will be beneficial.

Seeds, 25c per package.

\section{The New Novelty Seed Importing Co.}


